\title{
Prevalensi dan Gambaran Pola Luka Korban Kecelakaan Sepeda Motor di Instalasi Forensik RSUP Sanglah Denpasar Tahun 2013
}

\author{
Putu Herlin Oktavianti
}

Program Studi Pendidikan Dokter, Fakultas Kedokteran Universitas Udayana

Diterima: 5 Juni 2016. Disetujui: 15 Juni 2016. Diterbitkan: Agustus 2016

\begin{abstract}
ABSTRAK
Kecelakaan lalu lintas merupakan suatu peristiwa di jalan raya yang tidak diduga, tidak diinginkan, sulit diprediksi kapan dan dimana terjadinya. Sedikitnya melibatkan satu kendaraan dengan pengguna jalan lain atau akibat kelalaian dalam mengemudikan kendaraan baik itu mobil ataupun sepeda motor yang dapat menyebabkan kematian, kecacatan, luka berat, ataupun luka ringan. Setiap luka memiliki pola tertentu yang dapat membantu polisi untuk menentukan cara kematian pada korban, maka polisi memerlukan bantuan dokter untuk menyelidiki pola luka yang ditimbulkan. Tujuan penelitian ini adalah mengetahui pola luka korban kecelakaan lalu lintas pada pengendara sepeda motor menurut data di Instalasi Kedokteran Forensik RSUP Sanglah tahun 2013. Penelitian ini merupakan studi deskriptif retrospektif dengan pendekatan cross-sectional. Data skunder didapat dari data Bagian Instalasi Kedokteran Forensik RSUP Sanglah. Data penelitian ini dianalisis secara deskriptif. Pada 74 sampel dalam penelitian ini, proporsi jenis luka terbanyak adalah luka lecet sebanyak 72 sampel (97,3\%) sedangkan lokasi luka terbanyak, yaitu pada kepala dan wajah sebanyak 67 sampel (67,6\%). Dapat disimpulkan bahwa korban meninggal pada kecelakaan sepeda motor yang masuk ke Instalasi Kedokteran Forensik RSUP Sanglah kebanyakan mengalami luka di bagian kepala dan wajah dengan jenis luka lecet, memar, terbuka tumpul, dan patah tulang.
\end{abstract}

Kata kunci: kecelakaan lalu lintas, pola luka, lokasi luka

\section{PREVALENCE AND DESCRIPTION OF MOTORCYCLE ACCIDENT VICTIM AT FORENSIC INSTALLATION RSUP SANGLAH IN 2013}

\section{ABSTRACT}

Traffic accident is an event on the road that unexpected and unwanted or difficult to be predicted. It means that when the accident happened and where the accident occurrence, at least involved between one vehicle to the other "road user" or because of driver's negligence or between it's a car or a motorcycle and cause of death, disability, serious injury or minor injury. Every wounds have specific patterns that can help the police to determine how the death of the victim, the polices need doctor to help them to investigate the pattern of it. The purpose of this research is to determine the pattern of victims' injured because of traffic accident especially use motorcycle based on Forensic Medicine Installation's data in Sanglah 2013. This study is retrospective descriptive with cross sectional study. The secondary data were obtained from Forensic Medicine Installation in Sanglah. The data were analyzed descriptively. The researcher used 74 samples in her research consist of 72 samples $(97,3 \%)$ who was abrasion, mostly in their head and face 67 samples $(67 \%)$. The result that the victim who died because of used motorcycle because of they was injured in their head and face with their abrasions, bruises, laceration and fractures.

Keyword : traffic accident, injury patterns, and the location of its wound / wound's location. 
dengan pesatnya kemajuan teknologi, telah banyak alat transportasi sebagai sarana lalu lintas sehingga menyebabkan laju pertumbuhan kendaraan semakin meningkat. Selain memberi dampak positif bagi pemenuhan mobilisasi, terdapat juga dampak negatif yang tidak diinginkan seperti kemacetan, meningkatnya polusi udara, dan angka kecelakaan lalu lintas.

Kecelakaan lalu lintas merupakan suatu peristiwa pada lalu lintas jalan yang tidak diduga dan tidak diinginkan yang sulit diprediksi kapan dan dimana terjadinya, sedikitnya melibatkan satu kendaraan dengan pengguna jalan lain atau akibat kelalaian dalam mengemudikan kendaraan baik itu mobil ataupun sepeda motor yang dapat menyebabkan kematian, kecacatan, luka berat, ataupun luka ringan.

Dalam dua tahun terakhir ini, kecelakaan lalu lintas di Indonesia oleh WHO dinilai menjadi penyebab kematian terbesar ketiga di bawah penyakit jantung coroner dan tuberculosis/TBC. Data dari WHO tahun 2011, menyebutkan, sebanyak 67\% korban kecelakaan lalu lintas berada pada usia produktif, yakni 22-55 tahun. Terdapat sekitar 400.000 korban di bawah usia 25 tahun yang meninggal di jalan raya, dengan rata-rata angka kematian 1.000 anak-anak dan remaja setiap harinya. Bahkan, kecelakaan lalu lintas menjadi penyebab utama kematian anak-anak di dunia, dengan rentang usia 10-24 tahun. ${ }^{1,2}$

Data dari Polisi Nasional pada tahun 2008, ditemukan bahwa korban meninggal terbanyak pada kecelakaan adalah sepeda motor dengan presentase $61 \%$. Kemudian diikuti dengan pejalan kaki $15 \%$, sepeda $13 \%$, mobil penumpang $4 \%$, dan pengemudi roda empat $3 \%$ pada tiga provinsi di Indonesia. ${ }^{3}$

Meskipun angka kematian pada kecelakaan sepeda motor paling tinggi, namun pengguna sepeda motor terus meningkat tiap tahunnya karena sepeda motor masih menjadi andalan utama dan paling terjangkau bagi mayoritas penduduk, selain itu sepeda motor lebih praktis ditengah kemacetan. Membanjirnya jumlah pengguna motor juga didorong oleh kemudahan saat proses pembelian kendaraan tersebut. Tanpa memberi uang muka pun, seseorang dapat dengan mudah memiliki sepeda motor secara kredit.

Kecelakaan yang terjadi pada sepeda motor dapat menyebabkan luka-luka dari luka ringan hingga terjadinya kecacatan pada korban bahkan yang paling fatal dapat menyebabkan kematian. Luka merupakan suatu kerusakan fisik yang terjadi ketika tubuh manusia mengalami atau mendapat kontak yang akut (tiba-tiba) dari tingkat energi yang tidak tertahankan. Setiap luka memiliki pola tertentu yang dapat membantu polisi untuk menentukan cara kematian pada korban, maka polisi memerlukan bantuan dokter untuk menyelidiki kondisi korban kecelakaan yang dapat dilihat dari pola luka yang ditimbulkan.

Di sisi lain, kecelakaan tidak selalu ada saksi mata, oleh sebab itu polisi harus menentukan apakah kejadian tersebut merupakan terdapat unsur kesengajaan atau murni karena kecelakaan.

\section{METODE PENELITIAN \\ Rancangan Penelitian}

Penelitian ini menggunakan rancangan deskriptif retrospektif dengan pendekatan cross-sectional untuk menentukan prevalensi pola luka kecelakaan lalu lintas pada pengendara sepeda motor dengan menggunakan data dari Bagian Instalasi Kedokteran Forensik RSUP Sanglah.

Penelitian cross-sectional merupakan jenis penelitian dimana peneliti melakukan observasi atau pengukuran variable pada satu waktu tertentu.

\section{Disiplin Ilmu Terkait}

Penelitian ini merupakan penelitian yang multidisiplin dengan berbagai disiplin ilmu terkait berupa epidemiologi dan ilmu kedokteran forensik.

\section{Lokasi Penelitian}

Penelitian ini dilakukan di Bagian Instalasi Kedokteran Forensik RSUP Sanglah.

\section{Waktu Penelitian}

Penelitian ini diawali dengan proses perancangan tema, penyusunan proposal, pelaksanaan penelitian, pengumpulan dan analisis data, serta pembuatan laporan hasil penelitian yang dilaksanakan pada bulan Oktober 2013 sampai bulan November 2014.

\section{SUBJEK DAN SAMPEL Variabilitas Populasi}

1. Populasi Target 
Populasi target pada penelitian ini adalah semua korban meninggal pada pengendara sepeda motor di Denpasar

\section{Populasi Terjangkau}

Populasi terjangkau adalah semua korban meninggal pada pengendara sepeda motor yang datanya masuk ke bagian Instalasi Kedokteran Forensik RSUP Sanglah, Denpasar selama tahun 2013.

3. Sampel Penelitian

Sampel pada penelitian ini merupakan populasi terjangkau yang memenuhi kriteria inklusi dan tidak mempunyai kriteria eksklusi.

\section{Kriteria Subjek}

1. Kriteria Inklusi:

a) Korban meninggal pada pengendara sepeda motor di RSUP Sanglah, Denpasar pada tahun 2013

b) Seluruh data korban yang lengkap berdasarkan pemeriksaan luar jenazah dan keterangan dari kepolisian.

2. Kriteria Ekslusi:

a) Korban meninggal akibat kecelakaan lalu lintas namun tidak ada keterangan dari kepolisian.

b) Korban yang diduga meninggal karena kecelakaan lalu lintas tapi tidak dilakukan pemeriksaan jenazah.

\section{Besaran Sampel}

Jumlah sampel yang digunakan pada penelitian deskriptif ini adalah semua korban meninggal yang memenuhi kriteria inklusi dan eksklusi pada pengendara sepeda motor di RSUP Sanglah, Denpasar pada tahun 2013.

\section{Teknik Penentuan Sampel}

Teknik penentuan sampel pada penelitian ini adalah dengan metode consecutive sampling, semua data subjek (korban) yang masuk ke bagian Instalasi Kedokteran Forensik secara berurutan setiap bulannya dan memenuhi kriteria pemilihan dimasukkan dalam penelitian sampai jumlah subjek yang diperlukan terpenuhi.

\section{Variabel}

1.. Identifikasi Variabel
a) Jenis kelamin
b) Umur
c) Kewarganegaraan
d) Pekerjaan
e) Peran korban
f) Mekanisme kecelakaan
g) Jenis luka
h) Lokasi luka

\section{Definisi Operasional}

a. Jenis kelamin merupakan suatu ciri yang dapat membedakan korban satu dengan korban yang lain berdasarkan surat keterangan dari kepolisian yang dicocokkan dengan ciri atanomi korban yang dapat dilihat melalui pemeriksaan luar ataupun pemeriksaan dalam dan kemudian diklasifikasikan menjadi 2 kategori:

i. Laki-laki

ii. Perempuan

Skala ukur: nominal

b.Umur merupakan lamanya hidup korban yang dihitung dalam satuan tahun penuh sejak dilahirkan sampai tanggal pada saat terjadi kecelakaan. Umur digolongkan menjadi 3 kelompok meliputi :

i. $<17$ tahun

ii. $17-40$ tahun

iii. $>40$ tahun

Skala ukur: nominal

c. Kewarganegaraan yang dimaksud adalah kewarganegaraan korban yang tercantum dalam data kepolisian dan laporan pemeriksaan jenazah.

i. Indonesia

ii. Asing

Skala ukur: nominal

d. Pekerjaan yang dilakoni/sedang dijalani sebagai sumber penghasilan utama oleh korban kecelakaan pada saat terjadi kecelakaan.

i. PNS

ii. Swasta

iii. Pelajar

iv. Tidak bekerja

Skala ukur: nominal

e. Peran dari korban pada saat terjadi kecelakaan,hal yang dilakukan oleh korban kecelakaan lalu lintas 
pada saat terjadi kecelakaan lali lintas, diklasifikasikan menjadi 2 kategori:

i. Pengendara

ii. Penumpang

Skala ukur: nominal

f. Mekanisme kecelakaan merupakan suatu cara bagaimana kecelakaan tersebut terjadi \& dapat mengidentifikasi penyebab dari kecelakaan tersebut

i. Berhadapan

ii. Menabrak

iii. Out of control

Skala ukur: nominal

g. Jenis luka merupakan suatu sifat/tipe luka dari kecelakaan; yang mengidentifikasikan sifat dan kerusakan fisik korban karena kecelakaan tersebut.
i. Luka lecet
ii. Luka memar
iii. Luka terbuka tajam
iv. Luka terbuka tumpul
v. Patah tulang
vi. Luka terawat

Skala ukur: nominal

h. Lokasi luka merupakan letak kelainan atau luka yang dituimbulkan pada tubuh korban ketika terjadi kecelakaan.
i. Kepala dan wajah
ii. Leher
iii. Rongga dada dan perut
iv. Punggung, tulang belakang, pinggang, panggul, dan bokong
v. Bahu dan lengan atas
vi. Ketiak
vii. Siku dan lengan bawah
viii. Pergelangan dan telapak tangan
ix. Buah zakar
x. Pangkal paha dan paha
xi. Lutut, tungkai bawah, pergelangan, dan telapak kaki

Skala ukur: nominal

\section{Bahan dan Instrumen Penelitian}

Bahan dan instrument yang diperlukan dalam penelitian ini adalah berupa data sekunder. Dimana data sekunder adalah data korban meninggal karena kecelakaan lalu lintas dari Instalasi Kedokteran Forensik RSUP Sanglah, Denpasar tahun 2013.
Adapun teknik pengumpulan data pada penelitian ini adalah dengan mengumpulkan data dari seluruh korban meninggal pada pengendara sepeda motor di Instalasi Kedokteran Forensik RSUP Sanglah, Denpasar pada tahun 2013.

\section{Protokol Penelitian}

1. Mengajukan ethical clearance kepada Ketua Litbang Fakultas Kedokteran Universitas Udayana

2. Mengajukan surat permohonan ijin kepada Direktur RSUP Sanglah Denpasar untuk meminta data laporan pemeriksaan jenzah korban kecelakaan lalu lintas di Instalasi Kedoteran Forensik selama kurun waktu satu tahun (2013).

3. Lalu dilakukan penentuan sampel dengan cara teknik consecutive sampling, dimana semua data subjek (korban) yang masuk ke bagian Instalasi Kedokteran Forensik.

4. Selanjutnya, data-data yang diperlukan dan tercantum pada keterangan dari pihak kepolisian dan laporan pemeriksaan jenazah yang telah memenuhi kriteria kemudian dicatat.

\section{Analisis Data}

1. Pengolahan Data

a. Coding Data

Masing-masing kasus diberikan kode tertentu untuk mempermudah dalam entry dan analisis data.

b. Entry Data

Data dimasukkan secara komputerisasi setelah dibuat struktur entry data yang mencakup nomor, nama variabel, tipe variabel, width, decimals, variable labels, value labels, dan missing values.

c. Cleaning Data

Untuk menghindari kemungkinan adanya kesalahan dalam analisis data, data yang telah dimasukkan akan dicek kembali sehingga kesalahan data dapat segera diperbaiki.

\section{Teknik Analisis Data}

Data yang telah terkumpul kemudian diolah dan dianalisis secara deskriptif. Bentuk penyajian data dari masing-masing variabel dilakukan dengan :

Distribusi frekuensi: Semua data yang merupakan skala nominal disajikan dalam bentuk distribusi frekuensi baik berupa tabel maupun grafik.

\section{HASIL DAN PEMBAHASAN}


Pengambilan data melalui laporan pemeriksaan jenazah dan keterangan dari surat permintaan visum dari kepolisian pada kecelakaan lalu lintas dilaksanakan pada bulan April 2014 di Instalasi Kedokteran Forensik RSUP Sanglah dengan menggunakan metode consecutive sampling. Setelah dilakukan pengambilan sampel didapatkan 115 kasus yang masuk ke bagian Instalasi Kedokteran Forensik secara berurutan setiap bulannya, namun hanya 74 kasus yang menjadi sampel penelitian ini. Hal ini dikarenakan pada beberapa kasus terdapat ketidaklengkapan pada variable yang akan diteliti. Dari pengumpulan data, pengolahan dan analisis didapatkan hasil sebagai berikut.

\section{Karakteristik Sampel}

Tabel 1. Karakteristik Sampel

\begin{tabular}{lcc}
\hline \multicolumn{1}{c}{ Variabel } & N & $\%$ \\
Jenis Kelamin & & \\
Laki-laki & 56 & 75,7 \\
Perempuan & 18 & 24,3 \\
Umur & & \\
$<17$ tahun & 8 & 12,2 \\
17-40 tahun & 47 & 62,2 \\
$>40$ tahun & 19 & 25,7 \\
Kewarganegaraan & & \\
Indonesia & 69 & 93,2 \\
Asing & 5 & 6,8 \\
Pekerjaan & & \\
PNS & 4 & 5,4 \\
Swasta & 53 & 71,6 \\
Pelajar & 12 & 16,2 \\
Tidak bekerja & 5 & 6,8 \\
\hline
\end{tabular}

Dari data karakteristik sampel di atas, didapatkan bahwa kasus kecelakaan lalu lintas pengguna sepeda motor paling banyak terjadi pada laki-laki dengan jumlah 56 kasus (75,7\%). Pada penelitian ini, jumlah kasus pada laki-laki 3,1 kali lebih besar daripada perempuan. Hal ini serupa dengan data Riskesdes tahun 2007, didapatkan bahwa cedera akibat kecelakaan lalu lintas lebih tinggi pada lakilaki yaitu 31,9\% dibandingkan dengan perempuan yaitu sekitar $19,8 \%$. Penelitian yang dilakasanakan oleh Riyadina dan Subik (2007) di Instalasi Gawat Darurat RSUP Fatmawati Jakarta Selatan jumlah korban laki-laki (73,9\%) kira-kira tiga kali lebih banyak dari jumlah perempuan $26,1 \% .{ }^{4}$ Penelitian lain yang dilakukan di RSUPN Cipto Mangunkusumo juga menyatakan bahwa kejadian kecelakaan pada laki-laki 6,3 kali lebih besar dari perempuan. ${ }^{3}$ Hasil ini sesuai dengan studi WHO yang menunjukkan bahwa 73\% dari korban kecelakaan lalu lintas yang fatal adalah laki-laki. ${ }^{2}$ Hal ini diperkirakan karena laki-laki memiliki mobilitas yang lebih tinggi dan banyak beraktivitas di luar rumah untuk bekerja serta sepeda motor merupakan kendaraan yang paling banyak dipilih sebagai sarana transportasi. Diperkirakan bahwa pola berkendara dari kaum laki-laki yang lebih berani atau lebih nekat dibandingkan dengan kaum perempuan, sehingga berakibat pada meningkatnya risiko untuk terjadinya kecelakaan lalu lintas.

Variabel umur dibagi atas 3 kelompok, yaitu kelompok umur $<17$ tahun, 17-40 tahun, dan $>40$ tahun. Rata-rata umur pada sampel adalah 32,7 , dimana umur yang paling kecil adalah 12 tahun dan umur yang paling besar adalah 70 tahun. Kasus kecelakaan lalu lintas pada pengguna sepeda motor tertinggi terjadi pada kelompok umur 17-40 tahun dengan 47 kasus $(62,2 \%)$, terendah terjadi pada kelompok umur $<17$ tahun dengan jumlah 8 kasus $(12,2 \%)$. Hal ini didukung oleh penelitian yang dilakukan oleh Riyadina, dkk bahwa cedera akibat kecelakaan lalu lintas mayoritas dialami oleh kelompok umur dewasa (15-59 tahun) yaitu sebesar $38,8 \%(95 \% \mathrm{Cl} 38,0-39,5)$ dan berbeda bermakna $(p<0,001)$ untuk masing-masing kelompok umur. ${ }^{5}$ Penelitian terdahulu yang dilakukan oleh Riyadina dan Subik (2007), kematian akibat kecelakaan lalu lintas lebih dari separuhnya terjadi pada kelompok umur dewasa muda antara 15-44 tahun. ${ }^{4}$ Hasil ini sesuai dengan study WHO yang menyebutkan, sebanyak $67 \%$ korban kecelakaan lalu lintas berada pada usia produktif, yakni 22-55 tahun. Jadi dapat dilihat bahwa sebagian besar korban kecelakaan berada pada usia produktif yang memiliki tingkat mobilitas tinggi.

Korban meninggal pada kecelakaan lalu lintas pengguna sepeda motor tidak hanya Warga Negara Indonesia (WNI), terdapat pula 5 kasus $(6,8 \%)$ pada Warga Negara Asing (WNA). Adanya korban WNA berkaitan dengan daerah Bali yang merupakan tujuan wisata sehingga banyak WNA yang berkunjung. Berdasarkan pengamatan penulis, sebagian besar WNA tidak mengikuti tata tertib lalu lintas dalam mengendarai sepeda motor di Bali, 
seperti tidak mengenakan helm Standar Nasional Indonesia (SNI), rendahnya pemakaian APD (alat pelindung diri), melanggar rambu-rambu lalu lintas, kurangnya konsentrasi dalam berkendaraan, menggunakan ponsel saat mengemudi, boncengan tiga, dan bentuk pelanggaran lainny . Contoh kasus yang terjadi di Jalan Raya Batu Belig pada bulan Juni 2014, kecelakaan tersebut telah menelan satu korban jiwa WNA asal Prancis yang mengendarai sepeda motor dengan melakukan pelanggaran berupa bonceng tiga. ${ }^{6}$

Kasus kecelakaan paling banyak terjadi pada korban yang bekerja pada bidang swasta yaitu sebesar 53 kasus dengan presentase $71,6 \%$. Pelajar merupakan kategori kedua terbanyak yang mengalani kecelakaan, yaitu 12 kasus dengan presentase $16,2 \%$. Jumlah kasus yang paling sedikit terjadi pada kategori pekerjaan PNS yaitu 4 kasus dengan presentase $5,4 \%$. Hal ini dikarenakan presentase pegawai swasta lebih besar dari PNS. Serupa dengan penelitian pada RSUPN dr. Cipto Mangunkusumo yang menemukan bahwa pekerjaan korban paling banyak adalah pekerjaan yang bergerak di bidang swasta. Kemudian dikategorikan menjadi berkerja dan tidak bekerja, maka jumlah kasus terbanyak terjadi pada korban yang bekerja (78,7\%). Hal ini dapat diasumsikan bahwa orang yang bekerja lebih berisiko terkena kecelakaan karena mereka harus pergi ke tempat kerja dengan kendaraan ataupun berjalan kaki. Sedangkan yang tidak bekerja lebih tidah berisiko karena mereka hanya beraktivitas di rumah, tidak terlalu banyak beraktivitas di luar tempat tinggal mereka. $^{3}$

\section{Peran Korban}

Tabel 2. Peran Korban

\begin{tabular}{lcc}
\hline \multicolumn{1}{c}{ Variabel } & $\mathbf{N}$ & $\%$ \\
Peran Korban & & \\
Pengendara & 68 & 91,9 \\
Penumpang & 6 & 8,1 \\
\hline
\end{tabular}

Berdasarkan tabel 2 dapat diketahui bahwa kematian yang disebabkan karena kecelakaan lalu lintas lebih banyak dialami oleh pengendara sepeda motor, yaitu sebanyak 68 kasus kecelakaan $(91,9 \%)$ sedangkan kasus pada penumpang hanya terdapat 9 kasus (8,1\%). Serupa dengan penelitian Riyadina dan Subik (2007) yang mendapat korban kecelakaan sebanyak 138 orang. ${ }^{4}$ Dari jumlah tersebut yang menempati posisi sebagai pengemudi sebanyak 97 orang $(70,3 \%)$ dan sebagai penumpang sebanyak 41 orang $(29,7 \%)$. Selain itu, penelitian yang dilakukan di RSUPN dr. Cipto Mangunkusumo pada tahun 2003-2007 terdapat 468 kecelakaan (84,2\%) terjadi pada pengendara sepeda motor sedangkan pada penumpang hanya terdapat 91 kasus $(15,8 \%){ }^{3}$ Tingkat kematian pada penumpang lebih rendah daripada pengendara dikarenakan orang-orang lebih memilih membawa sepeda motor pribadi daripada menumpang kendaraan umum agar lebih praktis dalam menghindari kemacetan.

Hubungan Umur Korban dan Peran Korban

Tabel 3. Hubungan Umur Korban dan Peran Korban

\begin{tabular}{lcccc}
\hline \multirow{2}{*}{ Kelompok Umur } & \multicolumn{2}{c}{ Pengendara } & \multicolumn{2}{c}{ Penumpang } \\
& $\mathbf{N}$ & $\%$ & $\mathbf{N}$ & $\%$ \\
$<17$ & 7 & 9.5 & 1 & 1.4 \\
$17-40$ & 45 & 60.8 & 2 & 2.7 \\
$>40$ & 16 & 21.6 & 3 & 4.1 \\
\hline
\end{tabular}

Pada study ini, dari delapan korban meninggal pada kelompok umur < 17 tahun, tujuh korban berperan sebagai pengendara sepeda motor (tabel 3). Kelompok umur $<17$ tahun seharusnya dilarang mengendarai kendaraan karena kondisi psikologisnya yang cenderung masih labil dan belum mampu mengontrol emosi mereka ataupun keadaan sendiri yang berakibat tidak aman. Dan jelas peraturan di Indonesia melarang anak di bawah 17 tahun karena belum memiliki SIM (Surat Izin Mengemudi) yang syaratnya umur $>17$ tahun baru boleh memiliki SIM tersebut.

\section{Mekanisme Kecelakaan}

Berdasarkan data yang berhasil dikumpulkan dan memenuhi kriteria inklusi, hanya tujuh kasus yang mencantumkan mekanisme kecelakaan, dapat dilihat pada tabel berikut ini:

Tabel 4. Mekanisme Kecelakaan

\begin{tabular}{lcc}
\hline \multicolumn{1}{c}{ Variabel } & N & \% \\
Berhadapan & 3 & 4,1 \\
Menabrak & 1 & 1,4 \\
Out of control & 3 & 4,1 \\
Tanpa keterangan & 67 & 90,5 \\
\hline
\end{tabular}


Berdasarkan tabel diatas dapat diketahui bahwa dua jenis mekanisme kecelakaan memiliki proporsi yang sama, yaitu berhadapan dan out of control sebanyak tiga kasus (4,1\%). Hal ini dikarenakan pengendara sepeda motor kurang berhati-hati dalam mengendarai. Sebanyak 67 kasus $(90,5 \%)$ tanpa keterangan mekanisme kecelakaan penulis mengasumsikan bahwa informasi mengenai hal tersebut susah didapatkan sebab korban kehilangan kesadaran, ataupun mengalami amnesia retrograde, serta kurangnya saksi pada tempat kejadian.

Hendaknya data ini dicantumkan karena berkaitan dengan terapi yang akan diberikan, khususnya dalam hal ini pada pengendara sepeda motor terdapat gangguan konsentrasi akibat pengaruh obat-obatan, alkohol, dan lain-lain sehingga menyebabkan terjadinya kecelakaan out of control.

\section{Jenis Luka}

Pada penelitian ini lokasi luka dibagi menjadi beberapa kategori yakni luka lecet, luka memar, luka terbuka tajam, luka terbuka tumpul, patah tulang, dan luka terawat. Gambaran jenis luka pada korban meninggal kecelakaan lalu lintas dapat dilihat pada tabel 5 .

Tabel 5 Jenis Luka

\begin{tabular}{lcc}
\hline \multicolumn{1}{c}{ Variabel } & N & \% \\
\hline Luka lecet & 72 & 97,3 \\
Ada & 2 & 2,7 \\
Tidak & & \\
Luka memar & 48 & 64,9 \\
Ada & 26 & 35,1 \\
Tidak & & \\
Luka terbuka tajam & 2 & 2,7 \\
Ada & 72 & 97,3 \\
Tidak & & \\
Luka terbuka tumpul & 50 & 67,6 \\
Ada & 24 & 32,4 \\
Tidak & & \\
Patah tulang & 37 & 50 \\
Ada & 37 & 50 \\
Tidak & & \\
Luka terawat & 25 & 33,8 \\
Ada & 49 & 66,2 \\
\hline Tidak & & \\
\hline & &
\end{tabular}

Berdasarkan tabel 5 terlihat bahwa dari enam jenis luka empat jenis luka memiliki proporsi kejadian lebih dari $50 \%$ kasus, yaitu luka lecet 72 kasus (97,3\%), luka terbuka tumpul 50 kasus $(67,6 \%)$, luka memar 48 kasus $(64,9 \%)$, dan patah tulang 37 kasus (50\%). Terdapat 25 kasus kematian (33,8\%) memiliki jenis luka terawat. Sedangkan luka terbuka tajam memiliki proporsi kejadian terrendah yaitu hanya 2 kasus dari 74 kasus kematian akibat kecelakaan lalu lintas.

Hasil penelitian ini sesuai dengan teori yang menyatakan bahwa sebagian besar kecelakaan lalu lintas umunya menyebabkan luka akibat kekerasan benda tumpul. Yang termasuk kekerasan benda tumpul yaitu, luka lecet, luka memar, luka robek (luka terbuka tumpul), dan patah tulang. Hal ini didukung oleh penelitian Riyadina, dkk (2009) yang menemukan bahwa empat jenis luka terbanyak yaitu luka lecet sebesar 65,9\%, luka memar 49\%, luka terbuka $26,7 \%$, dan $21 \%$. $^{5}$

Adanya jenis luka terawat pada 25 sampel dikarenakan sebelum meninggal, korban dirawat di rumah sakit. Pada jenis luka terawat penyebab terjadinya perlukaan tidak bisa dinilai karena sudah di rawat, luka tersebut dapat disebabkan karena adanya prosedur operasi ataupun karena kejadian kecelakaan itu sendiri. Luka terawat hanya bisa diperkirakan berdasarkan lokasinya. Misalnya luka yang dikarenakan operasi laparotomi memiliki ciri luka di perut tepat di garis pertengahan tubuh.

Luka terbuka tajam merupakan jenis luka akibat kekerasan benda tajam, dimana pada kasus kecelakaan lalu lintas sangat jarang terjadi. Adanya jenis luka terbuka tajam pada sampel kemungkinan akibat terkena pecahan kaca spion ataupun bendabenda tajam di sekitar tempat kejadian perkara (TKP) saat terjadi kecelakaan.

Lokasi Luka

Tabel 6. Lokasi Luka

\begin{tabular}{lcc}
\hline \multicolumn{1}{c}{ Variabel } & N & $\%$ \\
Kepala dan wajah & & \\
Ada & 67 & 90.5 \\
Tidak & 7 & 9.5 \\
Leher & & \\
Ada & 27 & 36.5 \\
Tidak & 47 & 63.5 \\
Rongga dada dan perut & & \\
Ada & 43 & 58.1 \\
Tidak & 31 & 41.9
\end{tabular}




\section{Punggung, tulang belakang, pinggang, panggul, dan bokong}

Ada

$20 \quad 27$

Tidak

$54 \quad 73$

Bahu dan lengan atas

Ada

$50 \quad 67.6$

Tidak

$24 \quad 32.4$

Ketiak

Ada

Tidak

$0 \quad 0$

$74 \quad 100$

Siku dan lengan bawah

Ada

Tidak

Pergelangan dan telapak tangan

Ada

$47 \quad 63.5$

Tidak

$27 \quad 36.5$

Buah Zakar

Ada

Tidak

34

7196

Pangkal paha dan paha

Ada

$36 \quad 48.6$

Tidak

$38 \quad 51.4$

Lutut, tungkai bawah, pergelangan, dan telapak kaki

Ada

$64 \quad 86.5$

Tidak

$10 \quad 13.5$

Berdasarkan tabel 6 lokasi luka pada kepala dan wajah memiliki proporsi terbanyak, yaitu 67 kasus (90,5\%). Diikuti dengan lokasi pada lutut, tungkai bawah, pergelangan, dan telapak kaki sebanyak 64 kasus (86,5\%), bahu dan lengan atas 50 kasus $(67,6 \%)$, pergelangan dan telapak tangan 47 kasus $(63,5 \%)$, siku dan lengan bawah 46 kasus $(62,2 \%)$, rongga dada dan perut 43 kasus $(58,1 \%)$, pangkal paha dan paha 36 kasus (48,6\%), dan punggung, tulang belakang, pinggang, panggul, dan bokong 20 kasus (27\%). Kasus yang mengalami luka pada daerah ketiak tidak ada (0\%) berarti pada kasus kecelakaan lalu lintas tidak terjadi perlukaan pada daerah yang tersembunyi. Hanya tiga kasus (4\%) yang mengalami perlukaan di buah zakar.

Hasil penelitian ini serupa dengan penelitian yang telah dilakukan di rumah sakit lima provinsi di Indonesia, menunjukkan bahwa bagian tubuh yang luka paling banyak di kepala, kaki, dan tangan. ${ }^{7} \mathrm{Hal}$ ini sesuai dengan penelitian yang telah dilalukan di
Denmark yang menyakatakan bahwa pada kecelakaan sepeda motor umumnya terjadi luka pada kedua ekstrimitas tubuh.

Selain itu, penelitian yang telah dilakukan di IGD RSUP Fatmawati Jakarta Selatan menunjukkan daerah atau bagian tubuh yang dominan mengalami luka pada korban kecelakaan sepeda motor adalah kepala yaitu sebanyak 55,1\%, selanjutnya adalah bagian pergelangan kaki yaitu sebanyak $12,3 \%$ dan bagian lutut dan tungkai bawah yaitu sekitar 9,4\%. Luka pada daerah kepala selalu menempati urutan teraras dari luka yang dialami oleh pengendara sepeda motor. Hal tersebut berhubungan dengan pemakaian helm sebagai alat pelindung kepala. ${ }^{4}$ Luka pada kepala umumya bersifat parah dan menyebabkan $80 \%$ kematian. Pola luka pada kaki umumnya banyak, bisa disebabkan luka karena impak primer pada kaki, impak sekunder sebagai akibat benturan dengan bagian lain dari kendaraan lawan dan atau pada jalan raya, ataupun terjepitnya kaki pada sepeda motor. Umumnya terjadi jenis luka robek, lecet dan patah. Patah tulang pada kaki ataupun pelvis terjadi pada $55 \%$ kasusnya.

Menurut teori pola luka disekitar kelamin dan paha bagian dalam banyak dialami oleh pengendara sepeda motor jenis motor sport, terjadinya perlukaan pada daerah tersebut kemungkinan pada saat terjadinya kecelakaan, daerah kelamin korban terjepit ataupun mengalami benturan dengan tangki bensin motor. Pada penelitian ini, berdasarkan keterangan surat rujukan pihak kepolisian dari tiga kasus yang mengalami perlukaan pada buah zakar, satu sampel mengendarai motor sport yaitu Honda tiger. Dua sampel lainnya mengendarai motor CW yang kemungkinan pada saat kecelakaan korban meletakkan barang dalam jumlah yang banyak pada lantai motor sehingga menyebabkan benturan pada buah zakar korban. Hal ini diperlukan penyelidikan lebih lanjut.

\section{Hubungan Luka pada Rongga Dada dan Perut dengan Peran Korban}

Tabel 7. Hubungan Luka pada Rongga Dada dan Perut dengan Peran Korban

\begin{tabular}{lcccc}
\hline \multirow{2}{*}{ Peran Korban } & \multicolumn{2}{c}{ Pengendara } & \multicolumn{2}{c}{ Penumpang } \\
& N & $\%$ & N & $\%$ \\
Pengendara & 40 & 54,1 & 28 & 37,8 \\
Penumpang & 3 & 4,1 & 3 & 4.1 \\
\hline
\end{tabular}


lebih lama sehingga dapat mewakili populasi pada

Berdasarkan tabel 7 pengendara sepeda motor yang mengalami luka pada rongga dada dan perut sebanyak 40 kasus (54,1\%), sedangkan pada penumpang hanya tiga kasus. Ada kemungkinan terjadi luka pada perut pengendara motor, dalam hal ini usus terjepit diantara setang setir dan tulang belakang, namun pada pemeriksaan fisik hanya ada jejas pada bahu atau kulit perut. Menurut Idries (1997) bagi penumpang kendaraan sepeda motor tidak ditemukan kelainan yang khusus. ${ }^{8}$

\section{SIMPULAN}

Berdasarkan hasil dan pembahasan pada penelitian ini, maka dapat ditarik kesimpulan bahwa korban meninggal pada kecelakaan sepeda motor yang masuk ke Instalasi Kedokteran Forensik RSUP Sanglah kebanyakan mengalami luka di bagian kepada dan wajah dengan jenis luka lecet, memar, terbuka tumpul, dan patah tulang. Korban meninggal kecelakaan sepeda motor umumnya mengalami luka lebih dari satu (multiple injury) baik dari jenis ataupun lokasi luka.

\section{SARAN}

Dari hasil pembahasan dan simpulan dapat disarankan beberapa hal sebagai berikut :

1. Bagi instansi kesehatan dan tenaga medis didalamnya khususnya di RSUP Sanglah Denpasar agar meningkatkan proses pencatatan rekam medis karena data sekunder yang baik dan lengkap sehingga dapat dijadikan evaluasi untuk menghadapi masalah kesehatan di masa mendatang.

2. Bagi pihak kepolisian diperlukan keterangan mengenai kondisi di tempat kejadian perkara (TKP) dan mekanisme kecelakaan yang diperlukan dalam pencatatan kematian kaitannya dengan penyebab kematian dalam surat keterangan kematian yang diterbitkan oleh Rumah Sakit. Selain itu pihak kepolisian sebaik lebih ketat dalam mengeluarkan SIM yang syarat kepemilikan SIM harus berusia > 17 tahun dan telah lulus dalam ujian keterampilan mengemudi serta penggunaan SIM untuk wisatawan asing.

3. Perlu dilakukan penelitian lebih lanjut dengan jumlah sampel yang lebih besar dan waktu yang daerah tersebut.

\section{DAFTAR PUSTAKA}

1. WHO. 2011. International Statistical Classification of Disease and Related Health Problems. Tenth Revision: Geneva, Volume 1, 891-1031.

2. World Health Organization. World report on road traffic injury prevention. WHO; 2004. [Online] Available from: http://www.who.int/violence-injuryprevention. [Accessed 2 December 2013].

3. Oktaviana,F. 2008. "Pola Cedera Kecelakaan Lalu Lintas pada Kendaraan Bermotor Roda Dua Berdasarkan Data RSUPN Dr. Cipto Mangunkusumo, Jakarta Tahun 2003-2007". Jakarta: Universitas Indonesia.

4. Riyadina dan Subik 2007. Profil Keparahan Cedera pada Korban Kecelakaan Sepeda Motor di Instalasi Gawat Darurat RSUP Fatmawati. Universa Medicina, 26 (2), 64-72

5. Ryadina W., Suhardi, Permana. 2009. Pola dan Determinan Sosiodemografi Cedera Akibat Kecelakaan Lalu Lintas di Indonesia. Majalah Kedokteran Indonesia, 59 (10), 464-472.

6. Jasa Raharja, 2014. Kacab JR Bali Serahkan Santunan MD WNA Prancis. [Online]. Available from: http://www.jasaraharja.co.id/kacab-jrbali-serahkan-santunan-md-wna-

perancis,263527.html[Accessed 11 November 2014].

7. Suwadono, A. Road traffic collision in urban Indonesia, epidemiology and policy opportunities. Jakarta: Badan Penelitian dan Pengembangan Kesehatan, Departemen Kesehatan RI; 2002.

8. Idries, AM, 1997. Pedoman IImu Kedokteran Forensik. Jakarta: Binarupa Aksara.

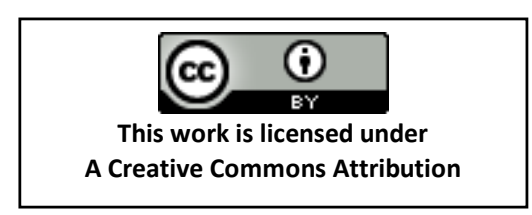

